\title{
Jumper Device
}

National Cancer Institute

\section{Source}

National Cancer Institute. Jumper Device. NCI Thesaurus. Code C50016.

A small connector designed to make temporary connections in electrical circuits. 